\title{
Determining the Profitability of Reniform Nematode Control Practices in the Mississippi Cotton Production System
}

\author{
Bradley R. Wilson, ${ }^{1}$ Thomas W. Allen, ${ }^{2,+}$ Angus L. Catchot, ${ }^{3}$ L. Jason Krutz, ${ }^{1}$ and Darrin M. Dodds ${ }^{1}$ \\ ${ }^{1}$ Department of Plant and Soil Sciences, Mississippi State University, Mississippi State, MS 39762 \\ ${ }^{2}$ Delta Research and Extension Center, Mississippi State University, Stoneville, MS 38776 \\ ${ }^{3}$ Department of Biochemistry, Entomology, Molecular Biology, and Plant Pathology, Mississippi State, MS 39762
}

Accepted for publication 11 March 2020.

\section{Abstract}

The reniform nematode, Rotylenchulus reniformis, can be damaging in silt loam soils that have predominantly supported cotton (Gossypium hirsutum L.) production in the Mid-Southern United States. The objective of this research was to determine the profitability of integrated nematode management options in Mississippi cotton production in soils naturally infested with the reniform nematode. Experiments were conducted near Hamilton, MS, in 2016 and Oswego and Tchula, MS, in 2017. Commercially available seed treatments included a base seed treatment of azoxystrobin + fludioxonil + mefenoxam and seedapplied nematicides including thiodicarb + imidacloprid and fluopyram. In-furrow nematicides included aldicarb and fluopyram + imidacloprid. Lastly, 1,3-dichloropropene was applied preplant to soil followed by cotton seed with and without treatment. Cotton yield was $40 \mathrm{~kg} / \mathrm{ha}$ greater when 1,3dichloropropene was applied, and a base fungicide seed treatment was utilized compared with the base seed treatment alone. Cotton yield was at least $73 \mathrm{~kg} / \mathrm{ha}$ greater when the base seed treatment was followed by aldicarb or fluopyram + imidacloprid in-furrow compared with seed treatments alone. Economic analyses suggested that seed treatment and in-furrow nematicides without 1,3-dichloropropene provided the greatest return on investment.

Keywords: nematology, integrated pest management, Gossypium hirsutum, Rotylenchulus reniformis, seed treatment, nematicides
Plant-parasitic nematodes are a major pest affecting cotton (Gossypium hirsutum L.) production (Starr et al. 2007; Weaver 2015). More specifically, the reniform nematode (Rotylenchulus reniformis [Linford \& Oliveira]) is the predominant nematode in cotton throughout the Mid-Southern United States and has been reported to cause estimated annual losses of approximately 20 million kilograms of seed cotton or $\$ 33$ million (Khanal et al. 2018; Lawrence et al. 2017, 2018; Robinson 2007). The reniform nematode was first identified in Georgia in 1940 (Smith 1940). Since 1940, the reniform nematode has been reported from all cotton-producing states in the United States and is the most important nematode in Alabama, Louisiana, and Tennessee (Gazaway and McLean 2003; Lawrence et al. 2017, 2018; Robinson 2007; Weaver et al. 2007). The reniform nematode can reduce cotton stand, exacerbate drought stress, reduce cotton plant growth, and reduce boll production (Lawrence and McLean 2000). In Mississippi as of 2010, the reniform nematode has been reported from 52 counties (NCC 2009).

Potential losses associated with specific nematodes are generally based on economic thresholds that consider the number of nematodes present in a given volume of soil (Ferris 1978). Economic thresholds for the reniform nematode are provided by the Mississippi

${ }^{\dagger}$ Corresponding author: T. W. Allen; tallen@drec.msstate.edu

Funding: The authors thank the Mississippi Cotton Incorporated State Support Committee for funding this research.

The author(s) declare no conflict of interest.

(C) 2020 The American Phytopathological Society
State University Extension Service and differ by the time of year when soil samples are collected as well as some minor differences in soil classification. In general, the economic threshold for reniform nematodes in Mississippi suggests that yield losses can occur when reniform nematode populations are at or above 211 vermiform reniform nematodes $/ 100 \mathrm{~cm}^{3}$ in the spring (at plant) and as high as 1,057 reniform nematodes $/ 100 \mathrm{~cm}^{3}$ by the end of the growing season (Patel 1999). Cotton farmers with reniform nematode populations greater than the defined threshold at planting are urged to implement management options to reduce economic losses.

Numerous methods have been proposed to manage the reniform nematode and reduce the likelihood of yield losses. However, reniform nematode management is difficult due to a high reproduction rate and the ability to overwinter deep in the soil profile (Heald and Orr 1994; Robinson et al. 2005a, 2005b). Cultural practices often provide limited benefit with respect to nematode population management and minimizing yield losses (Starr et al. 2007). Crop rotation, planting reniform nematode-resistant cover crops, and destroying crop residue can limit survival of the reniform nematode (Barker and Koenning 1998). Additionally, rotating with nonhost crops such as corn (Zea mays L.) or peanut (Arachis hypogaea L.) can effectively reduce reniform nematode populations; however, more than one season may be necessary to effectively reduce above-threshold reniform nematode populations (Starr et al. 2007; Stetina et al. 2007, 2009). Reniform nematoderesistant soybean (Glycine max [L.] Merr.) cultivars and winter grain crops, such as wheat (Triticum aestivum L.), can be rotated with cotton to reduce reniform nematode populations (Davis et al. 2003). However, for many farmers, rotation to crops other than 
cotton is not a viable practice because of fixed equipment costs and reduced returns from other agronomic crops (Zimet et al. 2002). When rotation with nonhost crops is not a viable option, cotton farmers can reduce production costs by implementing a no-till production system. Consequently, reports regarding the impact of no-till production systems on reniform nematode populations have varied, with some suggesting that tillage type did not result in an increase in reniform nematode populations (Westphal and Smart 2003), whereas still others report increased reniform nematode populations occurring in no-till irrigated systems (Cabanillas et al. 1999; Stetina et al. 2010). Even though host plant resistance is a potential management alternative, at present, there are no reniform nematode-resistant cotton cultivars commercially available (Khanal et al. 2018; Robinson 2007; Starr et al. 2007; Usery et al. 2005). However, in previous studies, some cotton cultivars were observed to exhibit more vigorous root growth, which may enhance the ability to tolerate reniform nematode populations better than cultivars with less vigorous root growth habits (Usery et al. 2005).

The primary management practice to reduce potential losses associated with the reniform nematode is use of nematicides. Several application methods for nematicides are available including soil fumigation, in-furrow application, and nematicides applied directly on the seed (Koenning et al. 2004; Lawrence and McLean 2001; Stetina et al. 2007). Preplant soil fumigants such as 1,3dichloropropene (as Telone II, Dow AgroSciences, Indianapolis, IN) are effective for management of nematode populations. Soil fumigants can provide protection to cotton roots in the absence of alternative nematicide treatments (Koenning et al. 2004). However, utilization of 1,3-dichloropropene in cotton has been limited due to chemical costs, need for specialized application equipment, and limited supply. Historically, aldicarb was widely used in cotton and provided early-season control of numerous thrips species as well as plant-parasitic nematodes (Hayes 1982; Howard 1991). Bayer CropScience voluntarily cancelled the aldicarb registration, and production was discontinued in 2010; however, a new aldicarb label (AgLogic 15G) has been obtained and was initially available in 2016 (EPA 2010, 2016). Limited data exist on the use of AgLogic aldicarb either alone or in combination with other products as an integrated approach to managing reniform nematode. Seed-applied pesticides are widely used in cotton production systems simply due to the ease of use and the fact that farmers have discontinued the use of insecticide boxes on their planters. However, seed-applied nematicide treatments provide minimal protection of cotton roots from nematode populations greater than the stated economic thresholds (Moore et al. 2010). Seed-applied nematicides typically provide nematode control for 3 to 4 weeks after planting in soils with low to moderate nematode populations (Layton and Reed 2002). In previous research, a seed treatment used in conjunction with aldicarb decreased nematode populations (Greene et al. 2007, 2008, 2009; Kemerait et al. 2009). Determining the potential integrated management approaches for managing the reniform nematode in an economic manner is important for farmers given the increasing nature of nematode infestations and production costs.

The objectives of the current study were (i) to evaluate nematode management practices on cotton growth, development, yield, and profitability as well as (ii) to determine if cultivar growth habit had an effect on cotton yield when grown in soils with reniform nematode populations above the threshold.

\section{Field Experiments}

Experiments were conducted in Hamilton, MS (Non-Delta) (Prentiss fine sandy loam) in 2016 and in Oswego (Delta) (Dubbs silt loam) and Tchula, MS (Delta) (Collins silt loam) in
2017 (Table 1). Experiments were conducted using a factorial arrangement of treatments ( $n=3$ factors) within a randomized complete block design with four replications. Plots consisted of four 97-cm-wide rows and $15 \mathrm{~m}$ in length in Hamilton and four 102-cmwide rows and $12 \mathrm{~m}$ in length in Oswego and Tchula. Factor A consisted of cotton cultivar $(n=2)$ and included PhytoGen 499 WRF (PhytoGen Cottonseed, Dow AgroSciences), which has an aggressive growth habit, and PhytoGen 222 WRF (PhytoGen Cottonseed), which has a passive growth habit. Cotton was seeded at a rate of 111,000 seeds/ha at a depth of $2.5 \mathrm{~cm}$. Factor B was nematicide application, which included seed-applied $(n=3)$ and infurrow $(n=2)$ treatments. Seed treatments were applied prior to planting using a metered slurry treater (Hege 11 Liquid Seed Treater, Wintersteiger, Salt Lake City, UT). Seed treatments included a base fungicide seed treatment package consisting of azoxystrobin at $0.013 \mathrm{mg}$ of active ingredient (a.i.)/seed + fludioxonil at $0.003 \mathrm{mg}$ of a.i./seed + mefenoxam at $0.009 \mathrm{mg}$ of a.i./ seed (as Dynasty CST, Syngenta Crop Protection, Greensboro, NC) and two different seed-applied nematicides that were applied to seed having already been treated with the base treatment and consisted of fluopyram at $0.3 \mathrm{mg}$ of a.i./seed (as $\mathrm{COPeO}$ Prime, Bayer CropScience, Research Triangle Park, NC) and imidacloprid at $0.375 \mathrm{mg}$ of a.i./seed + thiodicarb at $0.375 \mathrm{mg}$ of a.i./seed (as Aeris, Bayer CropScience). In-furrow nematicide applications included fluopyram at $0.24 \mathrm{~kg}$ of a.i./ha + imidacloprid at $0.34 \mathrm{~kg}$ of a.i./ha (as Velum Total, Bayer CropScience). In-furrow applications were made at planting using a 28-liters/ha carrier volume with XR8002E tips (TeeJet, Spraying Systems, Wheaten, IL). A second in-furrow nematicide application included a granular product as aldicarb at $0.84 \mathrm{~kg}$ of a.i./ha (as AgLogic 15G, AgLogic Chemical, Chapel Hill, NC). Factor $\mathrm{C}$ was a soil fumigant application consisting of 1,3-dichloropropene (as Telone II, Dow AgroSciences) applied at $33 \mathrm{~kg}$ of a.i./ha using a four-row applicator (Mirusso Enterprises, Delray Beach, FL) with deep-placement coulters (Yetter Manufacturing, Colchester, IL) placing the liquid at a depth of $31 \mathrm{~cm}$.

Insects, fertility, weed control, plant growth regulators, and harvest aids were managed based on Mississippi State University Extension Service recommendations (Bond et al. 2018; Catchot et al. 2017; Dodds 2017; Dodds et al. 2017). Nematode samples were collected prior to soil fumigant application, at planting, at first bloom, and at harvest using soil probes $(2.5 \mathrm{~cm}$ opening) to a depth of $15 \mathrm{~cm}$. Soil samples were collected from the center two rows of each plot by collecting eight soil cores from the root zone and combining into a single sample prior to placement in a plastic freezer bag for transportation back to the laboratory in coolers containing ice $\left(\approx 4^{\circ} \mathrm{C}\right)$. Nematodes were extracted from $300 \mathrm{~cm}^{3}$ of each soil sample using the North Carolina semiautomatic elutriator (Oostenbrink 1960). After elutriator extraction, the rapid sucrose centrifugal-flotation technique was used for separating nematodes from soil particles (Jenkins 1964). Reniform nematodes were enumerated based on morphological observations of the nematodes present in a germ count Petri dish using an inverted microscope at $\times 40$ magnification. Counts of the reniform nematodes present in each sample were made, and nematode values are presented based on $500 \mathrm{~cm}^{3}$ of soil.

Additional in-field data collection included stand counts made 21 days after planting, cotton height at first bloom and harvest, total nodes at first bloom and harvest, nodes above white flower (NAWF) at first bloom, nodes above cracked boll (NACB) prior to harvest, and seed cotton yield. The center two rows of each plot were mechanically harvested with a cotton picker modified for small plot research (Table 1). 
Data were subjected to analysis of variance using PROC Mixed in SAS (version 9.4, SAS Institute, Cary, NC), and means were separated using Fisher's protected least significant difference at $\alpha=$ 0.05 . Location and replication were considered random effects. Data regarding individual cultivars were analyzed separately, and because no significant interactions were observed on cotton growth parameters at first bloom, data were pooled for the additional analyses. Degrees of freedom were computed using the KenwardRoger method.

\section{Nematicide Cost Data Analysis}

Treatment costs were taken from the Mississippi State Agriculture Economic cotton budgets and were as follows: imidacloprid + thiodicarb $(\$ 45 / \mathrm{ha})$, azoxystrobin + fludioxonil + mefenoxam (\$29/ha), fluopyram (\$36/ha), aldicarb (\$74/ha), fluopyram + imidacloprid (\$93/ha), and 1,3-dichloropropene (\$130/ha) (Falconer et al. 2017). Net returns were determined above treatment cost using yield data and based on the average cotton selling price for 2016 and 2017. Cotton prices for the Delta were averaged between 2011 and 2016 and considered to be $\$ 1.80 /$ ha. An economic risk analysis using the stochastic efficiency model with respect to a function was used to determine the risk associated with the use of each nematicide treatment (Hardaker et al. 2004).

\section{Treatment Effects on Plant Growth Parameters, Reniform Nematode Populations, and Cotton Yield}

The effects of cultivar (factor A; $n=2$ ), treatment (factor B; $n=$ 6 ), and fumigant (factor $\mathrm{C} ; n=2$; with or without) resulted in a different level of responses depending on when parameters were evaluated. No significant differences were detected between cultivars for evaluations conducted at first bloom, and therefore data were pooled for the purposes of analysis and data presentation.

\section{TABLE 1}

Dates of soil fumigation, planting, and harvest for cotton field trials conducted in Hamilton, Oswego, and Tchula, MS, in 2016 and 2017

\begin{tabular}{lccc} 
Location & Soil fumigant date & Planting date & Harvest date \\
\hline Hamilton & 17 April 2016 & 10 May 2016 & 12 October 2016 \\
Oswego & 17 April 2017 & 11 May 2017 & 10 October 2017 \\
Tchula & 17 April 2017 & 19 May 2017 & 24 October 2017 \\
\hline
\end{tabular}

$\mathrm{z}$ 1,3-Dichloropropene was applied using a four-row applicator to a depth of $30 \mathrm{~cm}$.
Cultivar resulted in the lowest amount of response, given that only $10 \%$ of the variables considered were affected, and only parameters measured at first bloom were affected (Table 2). Treatment, taken as a whole of those individual treatments considered to be seed or infurrow treatments, resulted in an effect on $50 \%$ of the variables considered $(75 \%$ of the parameters considered at first bloom, but only one parameter at harvest) in addition to a significant effect on yield.

Stand counts 21 days after planting ranged from 94,576 to 105,469 plants/ha. A greater than $10 \%$ reduction in stand was observed in plots that were planted with base-treated seed followed by aldicarb at planting and fluopyram in-furrow compared with stand counts observed when seed treated with fluopyram was planted followed by fluopyram + imidacloprid in-furrow (Table 3). In addition, a greater than $8 \%$ reduction in stand was observed in plots planted with base-treated seed alone compared with stand counts following plots planted with seed treated with fluopyram followed by fluopyram + imidacloprid applied in-furrow (Table 3). Cotton height at first bloom ranged from 67 to $75 \mathrm{~cm}$. Application of a seed treatment alone resulted in cotton that was $10 \%$ shorter at first bloom compared with cotton that received a nematicide seed treatment and an in-furrow nematicide (Table 3). Cotton that received a preplant application of 1,3-dichloropropene was $11 \%$ taller at first bloom than cotton that did not receive 1,3-dichloropropene (Table 3). Cottonseed treated with a nematicide resulted in a 2 to $4 \%$ reduction in the total number of nodes at first bloom. However, greater node counts $(4 \%)$ were observed at first bloom when the base seed treatment was followed by fluopyram + imidacloprid infurrow compared with the base seed treatment alone. Cotton that received 1,3-dichloropropene prior to planting resulted in 3\% greater number of total nodes than cotton that did not receive 1,3dichloropropene (Table 3). Cotton seed with base seed treatment followed by fluopyram + imidacloprid in-furrow resulted in 3 to 4 , or $6 \%$ greater NAWF than all other treatments (Table 3). Application of 1,3-dichloropropene resulted in a $3 \%$ increase in NAWF at first bloom compared with cotton that did not receive 1,3dichloropropene (Table 3). Reniform nematode populations at first bloom were reduced by $54 \%$ following application of 1,3dichloropropene compared with plots that did not receive 1,3dichloropropene (Table 3).

Cotton that received a preplant application of 1,3-dichloropropene was $3.0 \%$ taller at harvest and produced a $3.8 \%$ greater yield than cotton that did not receive 1,3-dichloropropene (Table 4). Total NACB at the time of harvest aid application ranged from 3.8 to $4.5 \%$ depending on treatment combination (Table 4 ). The base seed treatment also resulted in a $14 \%$ increase in NACB at harvest compared with thiodicarb + imidacloprid seed treatment

\begin{tabular}{|c|c|c|c|c|c|c|c|c|c|c|c|}
\hline \multirow[b]{3}{*}{ Effect } & \multirow[b]{3}{*}{ DF } & \multirow[b]{3}{*}{$\begin{array}{l}\text { Stand } \\
\text { count }\end{array}$} & \multirow{2}{*}{\multicolumn{4}{|c|}{ First bloom parameters }} & \multirow{2}{*}{\multicolumn{4}{|c|}{ Harvest parameters }} & \multirow[b]{3}{*}{ Yield } \\
\hline & & & & & & & & & & & \\
\hline & & & $\begin{array}{l}\text { Plant } \\
\text { height }\end{array}$ & $\begin{array}{l}\text { Total } \\
\text { nodes }\end{array}$ & $\begin{array}{l}\text { Nodes above } \\
\text { white flower }\end{array}$ & $\begin{array}{l}\text { Nematode } \\
\text { count }\end{array}$ & $\begin{array}{l}\text { Plant } \\
\text { height }\end{array}$ & $\begin{array}{l}\text { Total } \\
\text { nodes }\end{array}$ & $\begin{array}{l}\text { Nodes above } \\
\text { cracked boll }\end{array}$ & $\begin{array}{l}\text { Nematode } \\
\text { count }\end{array}$ & \\
\hline Cultivar $^{\mathrm{x}}$ & 1 & 0.8619 & 0.4060 & 0.1961 & 0.0050 & 0.7733 & 0.4672 & 0.1104 & 0.0766 & 0.4676 & 0.8071 \\
\hline
\end{tabular}

${ }^{\mathrm{x}}$ Cultivar: PhytoGen $222 \mathrm{WRF}$ or PhytoGen 499 WRF.

y Treatment: (i) seed treatment (azoxystrobin + fludioxonil + mefenoxam; fluopyram; thiodicarb + imidacloprid) and (ii) in-furrow (aldicarb; fluopyram + imidacloprid).

${ }^{\mathrm{z}}$ Soil fumigant: 1,3-dichloropropene. 
(Table 4). Cotton lint yield ranged from 954 to $1,059 \mathrm{~kg} / \mathrm{ha}$ depending on treatment composition. Seed treated with the base seed treatment followed by fluopyram + imidacloprid in-furrow resulted in a $1.5 \%$ greater lint yield than the base seed treatment plus in-furrow aldicarb (Table 4). Seed treated with the base seed treatment, base seed treatment in combination with thiodicarb + imidacloprid, and fluopyram resulted in 9, 10, and 10\% less yield, respectively, compared with base-treated seed plus infurrow fluopyram + imidacloprid (Table 4). Soil treated with 1,3-dichloropropene resulted in $4 \%$ greater lint yield compared with when 1,3-dichloropropene was not included (Table 4).

\section{Profitability of Nematode Control Options}

A risk analysis was used to determine profitability of treatments above treatment cost. Costs of each treatment with and without 1,3dichloropropene are presented in Table 5. Treatment cost increased by 50 and $82 \%$ when 1,3-dichloropropene was added to the fluopyram seed treatment followed by in-furrow fluopyram +

\begin{tabular}{|c|c|c|c|c|c|}
\hline \multicolumn{6}{|c|}{$\begin{array}{l}\text { TABLE } 3 \\
\text { Cotton growth parameters and nematode counts at first bloom as affected by seed treatment (ST), in-furrow application (IF), and } \\
\text { soil fumigant application in Hamilton, Oswego, and Tchula, MS, in } 2016 \text { and } 2017\end{array}$} \\
\hline Effect & $\begin{array}{l}\text { Stand counts } \\
\text { (plants/ha) })^{x, y, z}\end{array}$ & $\begin{array}{c}\text { Plant } \\
\text { height }(\mathbf{c m})^{y, z}\end{array}$ & $\begin{array}{l}\text { Number of } \\
\text { total nodes } y, z\end{array}$ & $\begin{array}{c}\text { Number of } \\
\text { nodes above } \\
\text { white flowery,z }\end{array}$ & $\begin{array}{l}\text { Number of nematodes } \\
\text { (per } 500 \mathrm{~cm}^{3} \text { of soil)y,z }\end{array}$ \\
\hline $\begin{array}{l}\text { Azoxystrobin }+ \text { fludioxonil }+ \\
\quad \text { mefenoxam }(\mathrm{ST})+\text { aldicarb (IF) }\end{array}$ & $94,724 \mathrm{c}$ & 73 a & $12.5 \mathrm{a}$ & $6.5 \mathrm{~b}$ & 6,582 \\
\hline $\begin{array}{l}\text { Fluopyram (ST) + fluopyram + } \\
\text { imidacloprid (IF) }\end{array}$ & 105,469 a & 75 a & $12.4 \mathrm{a}$ & $6.6 \mathrm{~b}$ & 6,755 \\
\hline Fluopyram (ST) & $94,576 \mathrm{c}$ & $67 \mathrm{~b}$ & $12.1 \mathrm{~b}$ & $6.4 \mathrm{~b}$ & 5,182 \\
\hline Thiodicarb + imidacloprid (ST) & $102,282 \mathrm{abc}$ & $69 \mathrm{~b}$ & $12.1 \mathrm{~b}$ & $6.4 \mathrm{~b}$ & 7,362 \\
\hline 1,3-Dichloropropene & 99,788 & 75 a & $12.5 \mathrm{a}$ & $6.6 \mathrm{a}$ & $4,365 \mathrm{~b}$ \\
\hline None & 99,294 & $67 \mathrm{~b}$ & $12.1 \mathrm{~b}$ & $6.4 \mathrm{~b}$ & 9,457 a \\
\hline$P$ value & 0.8488 & $<0.0001$ & $<0.0001$ & 0.0195 & $<0.0001$ \\
\hline
\end{tabular}

${ }^{\mathrm{x}}$ Stand counts were conducted 21 days after planting.

${ }^{y}$ Data were pooled across cultivar $(n=2)$ and location $(n=3)$ because no interactions were observed.

${ }^{\mathrm{z}}$ Means within a column followed by the same letter are not significantly different based on Fisher's protected least significant difference $(P \leq 0.05)$.

\begin{tabular}{|c|c|c|c|c|}
\hline \multicolumn{5}{|c|}{ 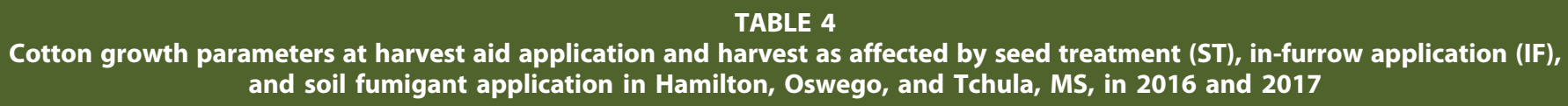 } \\
\hline Effect & $\begin{array}{l}\text { Plant height at } \\
\text { harvest }(\mathbf{c m})^{x, y}\end{array}$ & $\begin{array}{l}\text { Number of total } \\
\text { nodes } x, y\end{array}$ & $\begin{array}{l}\text { Number of } \\
\text { NACB }^{x, y, z}\end{array}$ & Yield (kg/ha) $)^{x, y}$ \\
\hline $\begin{array}{l}\text { Azoxystrobin + fludioxonil + mefenoxam } \\
(\mathrm{ST})+\text { aldicarb (IF) }\end{array}$ & 111.0 & 19.9 & $3.9 \mathrm{bc}$ & $1,043 \mathrm{a}$ \\
\hline Fluopyram (ST) + fluopyram + imidacloprid (IF) & 111.0 & 19.9 & $3.9 \mathrm{bc}$ & $1,014 \mathrm{ab}$ \\
\hline Fluopyram (ST) & 110.0 & 20.1 & $4.5 \mathrm{a}$ & $954 \mathrm{~b}$ \\
\hline Thiodicarb + imidacloprid (ST) & 111.0 & 20.1 & $3.8 \mathrm{c}$ & $955 \mathrm{~b}$ \\
\hline Azoxystrobin + fludioxonil + mefenoxam $(\mathrm{ST})$ & 109.0 & 20.1 & $4.4 \mathrm{ab}$ & $970 \mathrm{~b}$ \\
\hline$P$ value & 0.9234 & 0.9234 & 0.0456 & 0.0010 \\
\hline \multicolumn{5}{|l|}{ Soil fumigant } \\
\hline
\end{tabular}

${ }^{\mathrm{x}}$ Data were pooled across cultivar $(n=2)$ and location $(n=3)$ because no interactions were observed.

${ }^{y}$ Means within a column followed by the same letter are not significantly different based on Fisher's protected least significant difference $(P \leq 0.05)$.

${ }^{\mathrm{z}} \mathrm{NACB}=$ nodes above cracked boll at time of harvest aid application. 
imidacloprid and the base seed treatment package, respectively. The risk analysis presents probabilities of treatment providing net return below $\$ 1,235 /$ ha (below $\$ 1,235 /$ ha was classified as a negative return on investment and would result in loss of revenue), between $\$ 1,235$ and $\$ 1,729 /$ ha (indicates a positive return on investment; however, return on investment may be minimal), and above $\$ 1,729 /$ ha (indicates a positive return on investment) (Fig. 1). On average, seed treatment products applied alone resulted in a $28 \%$ probability of net returns above \$1,729/ha (Fig. 1). In-furrow products applied alone and averaged together resulted in $37 \%$ probability of a net return above $\$ 1,729 /$ ha. Application of base seed treatment + in-furrow nematicides were at least $7 \%$ more probable to have net returns above $\$ 1,729 / \mathrm{ha}$ compared with seed-applied nematicides following base seed treatment. However, when averaged across all treatments, adding 1,3dichloropropene as a treatment combination resulted in a less than $0.5 \%$ decrease in probability compared with the stand-alone seed treatments but a $9 \%$ decrease in probability of net returns above $\$ 1,729 /$ ha.

\section{Conclusions and Management Implications}

At present, commercial cultivars with resistance to the reniform nematode are not available. However, previous research has indicated there are inherent differences that trend toward tolerance

\begin{tabular}{|c|c|c|}
\hline \multicolumn{3}{|c|}{ 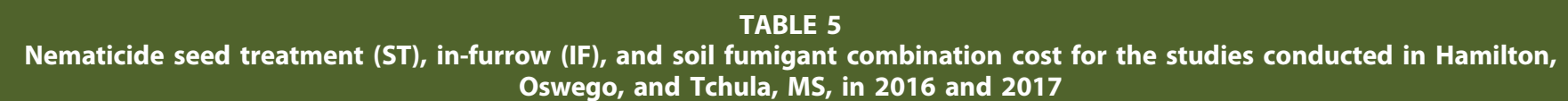 } \\
\hline Treatment & Cost $(\$ / h a)^{y}$ & $\begin{array}{l}\text { Cost with 1,3- } \\
\text { dichloropropene } \\
(\$ / \mathrm{ha})^{2}\end{array}$ \\
\hline Azoxystrobin + fludioxonil + mefenoxam (ST) + aldicarb (IF) & 103.00 & 233.00 \\
\hline Azoxystrobin + fludioxonil + mefenoxam (ST) + fluopyram + imidacloprid (IF) & 122.00 & 252.00 \\
\hline Thiodicarb + imidacloprid (ST) & 45.00 & 175.00 \\
\hline Azoxystrobin + fludioxonil + mefenoxam $(\mathrm{ST})$ & 29.00 & 159.00 \\
\hline Fluopyram (ST) & 36.00 & 166.00 \\
\hline
\end{tabular}

y Costs of nematicide treatments were taken from the Mississippi State University Agriculture Economic cotton budgets (Falconer et al. 2017).

${ }^{\mathrm{z}}$ Cost of nematicide treatments plus 1,3-dichloropropene.

\begin{tabular}{|c|c|c|c|c|c|c|c|c|c|c|c|c|}
\hline \multirow{3}{*}{$\begin{array}{r} \\
100 \% \\
90 \% \\
80 \% \\
70 \% \\
60 \% \\
50 \% \\
40 \% \\
30 \% \\
20 \% \\
10 \% \\
0 \%\end{array}$} & & & & \multicolumn{7}{|c|}{$=\$ 1,729 / \mathrm{ha} \quad \$ 1,235-\$ 1,729 / \mathrm{ha} \quad \square<\$ 1,235 / \mathrm{ha}$} & \multirow[b]{2}{*}{$29 \%$} & \multirow[b]{2}{*}{$38 \%$} \\
\hline & $25 \%$ & $29 \%$ & $29 \%$ & $25 \%$ & $28 \%$ & $30 \%$ & $31 \%$ & $41 \%$ & $24 \%$ & $31 \%$ & & \\
\hline & $54 \%$ & $55 \%$ & $55 \%$ & $54 \%$ & $48 \%$ & $56 \%$ & $60 \%$ & $180 \%$ & $59 \%$ & $54 \%$ & $57 \%$ & $50 \%$ \\
\hline & 1 & 2 & 3 & 4 & 5 & 6 & 7 & 8 & 9 & 10 & 11 & 12 \\
\hline \# & Treatmen & & & & & & \# & Treatmen & & & & \\
\hline 1 & Base (ST) & $+1,3-\mathrm{di}$ & loropro & bene & & & 7 & Base (ST & & & & \\
\hline 2 & Base (ST) & + Velun & tal (IF) & $+1,3$-dicl & broprope & & 8 & Base (ST & + fluopy & $m+\mathrm{imi}$ & acloprid & \\
\hline 3 & Fluopyram & (ST) + & 3-dichlo & ropropene & & & 9 & Fluopyran & (ST) & & & \\
\hline 4 & $\begin{array}{l}\text { Fluopyram } \\
\text { 1,3-dichlo }\end{array}$ & $\begin{array}{l}(\mathrm{ST})+ \\
\text { oprone }\end{array}$ & opyram & + imidacl & rid (IF) & & 10 & Fluopyran & $(\mathrm{ST})+f$ & opyram & imidacl & orid (IF) \\
\hline 5 & Thiodicark & + imida & prid (S & T) + 1,3-d & loropro & & 11 & Thiodicart & + imida & oprid (S & & \\
\hline 6 & Base (ST) & + aldica & $(\mathrm{IF})+1$ & ,3-dichlor & ropene & & 12 & Base (ST & + aldica & $(\mathrm{IF})$ & & \\
\hline
\end{tabular}

Base seed treatment (ST) comprised azoxystrobin + fludioxonil + mefenoxam.

FIGURE 1

Percent probability of net returns above treatment cost based on 12 treatments applied to two different cotton cultivars in several different treatment combinations on trials to manage the reniform nematode in the Mississippi cotton production system. 
to reniform nematodes within commercially available cultivars, but some researchers suggest the tolerance observed may not be consistent (Blessitt et al. 2012; Koenning et al. 2000; Usery et al. 2005). Breeding programs continue to work toward reniform nematode-resistant cultivars that may be commercially available as early as 2020 (Khanal et al. 2018; Stetina et al. 2007). In previously published research, cultivar was reported to provide differential yield responses in situations in which severe reniform nematode infestations were observed (Usery et al. 2005). In the current study, no differences in cotton yield or growth characteristics at first white flower were observed as a result of cultivar. Even though selected research suggests that cotton plant growth habit might impact responses to the reniform nematode, their data indicate that growth habit did not have an effect on cotton yield in situations in which above-threshold reniform nematode populations were present (Usery et al. 2005). Therefore, using available reniform nematode management tools including seed-applied nematicides and in-furrow treatments are the most advantageous management options for cotton farmers.

Applying a fungicide seed treatment (base treated) followed by an in-furrow nematicide resulted in greater probability of producing increased net returns compared with seed treatments alone. Historically, in-furrow aldicarb applications were the most widely used nematicidal applications in cotton (Khanal et al. 2018; Koenning et al. 2004). Davis et al. (2003) reported an increase in cotton yield when aldicarb was applied in-furrow in nematode-infested soils. In addition to the in-furrow application of aldicarb, fluopyram + imidacloprid in-furrow provided economically beneficial results greater than aldicarb. Previous research supports these results and suggest that an in-furrow application of fluopyram + imidacloprid provides better results than a seed-applied nematicide with regards to nematode suppression and potential yield benefits (Lawrence et al. 2014, 2015). Fluopyram is a fungicide in the succinate dehydrogenase inhibitor class, which has been observed to have nematicidal properties (Faske and Hurd 2015). In situations in which cotton farmers encounter reniform nematode populations greater than the economic threshold to begin the season, a base fungicide seed treatment package plus an in-furrow nematicide should be used at planting to reduce early-season nematode pressure, possibly resulting in increased cotton lint yield.

Even though nematicide seed treatments provide relative ease of application, are considered low risk, and can provide early-season protection from low to moderate nematode populations, cotton yield may be reduced when above-threshold nematode populations are present at planting (Monfort et al. 2006). In addition, the benefits of seed-applied nematicides are relatively short-lived, providing at most 14 days of protection postplanting (Monfort et al. 2006). Protecting cotton roots from reniform nematode feeding shortly after germination has previously been stated to be critical to establishing optimum yield (NCC 2007; Penteado et al. 2005). Moreover, previous reports on nematicide seed treatments have suggested some variability in abamectin-based products in reniform nematode-infested soils (Monfort et al. 2006). Similar results were observed in the current study, whereby nematicide seed treatments did not perform as well as in-furrow nematicides. Previous research has observed similar results with respect to the effectiveness of seed-applied nematicides compared with aldicarb (Wheeler et al. 2013). Seed-applied nematicides appear to be a better fit for field situations with below-threshold reniform nematode pressure.

The soil fumigant 1,3-dichloropropene has been both widely researched and the predominant fumigant nematicide in cotton production systems (Kemerait et al. 2008; Koenning et al. 2007;
Starr et al. 2007; Wheeler et al. 2014). 1,3-Dichloropropene is a viable option to protect cotton roots from nematodes and increase cotton yield. In the current study, cotton yield was increased following application of 1,3-dichloropropene. In addition, all measured variables were enhanced following application of 1,3dichloropropene as well as substantial reductions in the reniform nematode population. The results of the current research agree with Koenning et al. (2007), who reported increased cotton yield following a preplant soil fumigant application. In addition, Lawrence et al. (1990) indicated 38 to $81 \%$ reductions in reniform nematode populations following application of 1,3-dichloropropene. However, the current economic analysis suggested that treatment combinations including 1,3-dichloropropene were not economically advantageous when compared with other nematicide products. Wrather et al. (2002) hypothesized that nematode management inputs are typically squandered when nematicides are applied at one rate over an entire field given that nematode populations are generally not distributed uniformly across production fields and tend to vary across soil textural classes as well as horizontally and vertically within the soil profile (Khalilian et al. 2001, 2002). Sitespecific application of fumigant nematicides may reduce the costs associated with fumigant products (Overstreet et al. 2014). Using site-specific nematicide applications can reduce economic inputs while increasing cotton yield (Khalilian et al. 2002; Lohmeyer et al. 2003). However, most farmers do not have the equipment necessary to make site-specific fumigant applications. Moreover, high toxicity is a concern for chemical applicators, and there have also been supply-chain issues that have limited product availability across a much greater range.

When cotton farmers attempt to manage above-threshold reniform nematode populations, using an integrated management approach that considers cultivar, base fungicide seed treatment, and an in-furrow product with nematicidal properties may be beneficial in situations in which rotation options are limited. Given the results of the current research, farmers should be mindful that seedtreatment nematicides alone may not provide protection in situations in which reniform nematode population densities are substantially above the economic threshold. In addition, farmers should be mindful that decisions to manage reniform nematode populations need to be based on economic strategies, and in some cases products with nematicidal properties may be dangerous to apply as well as not economically beneficial.

\section{Literature Cited}

Barker, K. R., and Koenning, S. R. 1998. Developing sustainable systems for nematode management. Annu. Rev. Phytopathol. 36:165-205.

Blessitt, J. A., Stetina, S. R., Wallace, T. P., Smith, P. T., and Sciumbato, G. L. 2012. Cotton (Gossypium hirsutum) cultivars exhibiting tolerance to the reniform nematode (Rotylenchulus reniformis). Int. J. Agron. 2012: 893178.

Bond, J. A., Dodds, D. M., Golden, B. R., Irby, J. T., Larson, E. J., Lawrence, B. H., Reynolds, D. B., and Sarver, J. M. 2018. 2018 Weed Management Suggestion for Mississippi Row Crops. Publication 3171. Mississippi State University, Starkville, MS.

Cabanillas, H. E., Bradford, J. M., and Smart, J. R. 1999. Effect of tillage system, soil type, crop stand, and crop sequence on reniform nematodes after harvest. Nematropica 29:137-146.

Catchot, A. L., Allen, C., Bibb, J., Cook, D., Crow, W., Dean, J., Fleming, D., Gore, J., Layton, B., Little, N., MacGown, J., Musser, F., Winter, S., Dodds, D., Irby, T., Larson, E., and Meyers, S. 2017. 2017 Insect Control Guide for Agronomic Crops. Publication 2471 Mississippi State University, Starkville, MS.

Davis, R. F., Koenning, S. R., Kemerait, R. C., Cummings, R. C., and Shurley, T. D. 2003. Rotylenchulus reniformis management in cotton with crop rotation. J. Nematol. 35:58-64. 
Dodds, D. M. 2017. Cotton: Plant Growth Regulator Use. Mississippi Crop Situation. https://www.mississippi-crops.com/2017/07/07/cotton-plantgrowth-regulator-use/.

Dodds, D. M., Fromme, D., Cutts, T., Sandlin, T., Raper, T. B., and Robertson, B. 2017. 2017 Mid-South cotton defoliation guide. Midsouth Cotton Specialists Working Group. https://news.utcrops.com/wp-content/uploads/2017/ 09/W376.pdf.

Environmental Protection Agency. 2010. Pesticides: Reregistration. Agreement to terminate all uses of aldicarb. EPA, Washington, DC. https:// archive.epa.gov/pesticides/reregistration/web/html/aldicarb_fs.html.

Environmental Protection Agency. 2016. Pesticide product label: AgLogic 15G. EPA, Washington, DC. https://www3.epa.gov/pesticides/chem_search/ppls/ 087895-00004-20160817.pdf.

Falconer, L., Dodds, D., Bond, J., Catchot, A., Cook, D., Golden, B., Gore, J., Oldham, L., and Pringle, H. C. 2017. Cotton 2018 Planning Budgets. Department of Agricultural Economics, Budget Report 2017-01. Mississippi State University, Mississippi State, MS.

Faske, T. R., and Hurd, K. 2015. Sensitivity of Meloidogyne incognita and Rotylenchulus reniformis to fluopyram. J. Nematol. 47:316-321.

Ferris, H. 1978. Nematode economic thresholds: Derivation, requirements, and theoretical considerations. J. Nematol. 10:341-350.

Gazaway, W. S., and McLean, K. S. 2003. A survey of plant-parasitic nematodes associated with cotton in Alabama. J. Cotton Sci. 7:1-7.

Greene, J., Henderson, W., Khalilian, A., Mueller, J., Robinson, D., and Reeves, R. 2009. Precision-applied in-furrow nematicide/insecticide and seed treatment adoption in cotton-2008. Pages 1141-1142 in: Proc. Beltwide Cotton Conf. San Antonio, TX.

Greene, J., Mueller, J. D., Robinson, D., and Bonnette, W. W. 2007. Comparisons of nematicide/insecticide seed treatment and in-furrow products. Pages 279-280 in: Proc. Beltwide Cotton Conf. New Orleans, LA.

Greene, J., Robinson, D., Bonnette, W. W., Walker, T., Croft, J. K., and Reay Jones, F. P. F. 2008. Efficacy of insecticide/nematicide in-furrow and seed treatment products in South Carolina -2007. Pages 1406-1407 in: Proc. Beltwide Cotton Conf. Nashville, TN.

Hardaker, B. J., Richardson, J. W., Gudbrand, L., and Schumann, K. D. 2004. Stochastic efficiency analysis with risk aversion bounds: A simplified approach. Aust. J. Agric. Resour. Econ. 48:253-270.

Hayes, W. J., Jr. 1982. Pesticides Studied in Man. Waverly Press, Baltimore, MD.

Heald, C. M., and Orr, C. C. 1994. Nematode parasites of cotton. Pages 147-166 in: Plant and Insect Nematodes. W. R. Nickle, ed. M. Dekker, New York, NY.

Howard, P. H. 1991. Handbook of Environmental Fate and Exposure Data for Organic Chemicals. Lewis Publishers, Chelsea, MI.

Jenkins, W. R. 1964. A rapid centrifugal-flotation technique for separating nematodes from soil. Plant Dis. Rep. 48:692.

Kemerait, R. C., Roberts, P., Brewer, C. L., Brown, S. N., Harrison, W. E., Mitchell, B. R., McDaniel, R. G., and McNeill, R. D. 2009. Efficacy of nematicides with thrips management considerations on southern root-knot, Columbia, and lance nematodes in Georgia. Page 389 in: Proc. Beltwide Cotton Conf. San Antonio, TX.

Kemerait, R. C., Shurley, W. D., Ziehl, A. R., Sanders, F. H., Davis, R. F., Brown, S. M., Brown, S. N., McGriff, D. E., Mickler, K. D., Spaid, D. G., Harrison, W. E., Mitchell, B. R., Geard, G. H., Von Waldner, M. D., Duffie, W. D., Dollar, M., and Rucker, K. 2008. Assessment of efficacy and economic returns for nematicides applied in Georgia. Pages 245-257 in: Proc. Beltwide Cotton Conf. Nashville, TN.

Khalilian, A., Mueller, J. D., Han, Y. J., and Wolak, F. J. 2001. Predicting cotton nematodes distribution utilizing soil electrical conductivity. Pages 146-147 in: Proc. Beltwide Cotton Conf. Memphis, TN.

Khalilian, A., Mueller, J. D., Lewis, S., and Han, Y. J. 2002. Relationship of Columbia lance and root-knot nematodes to soil type. Page 236 in: Proc. Beltwide Cotton Conf. Atlanta, GA.

Khanal, C., McGawley, E. C., Overstreet, C., and Stetina, S. R. 2018. The elusive search for reniform nematode resistance in cotton. Phytopathology 108:532-541.

Koenning, S. R., Barker, K. R., and Bowman, D. T. 2000. Tolerance of selected cotton lines to Rotylenchulus reniformis. J. Nematol. 32:519-523.

Koenning, S. R., Kirkpatrick, T. L., Starr, J. L., Wrather, J. A., Walker, N. R., and Mueller, J. D. 2004. Plant-parasitic nematodes attacking cotton in the United States. Plant Dis. 88:100-113.

Koenning, S. R., Morrison, D. E., and Edmisten, K. L. 2007. Relative efficacy of selected nematicides for management of Rotylenchulus reniformis in cotton. Nematropica 37:227-235.

Lawrence, G. W., and McLean, K. S. 2000. Effect of foliar applications of oxamyl with aldicarb for the management of Rotylenchulus reniformis on cotton. J. Nematol. 32:542-549.
Lawrence, G. W., and McLean, K. S. 2001. Reniform nematode. Pages $42-43$ in: Compendium of Cotton Diseases, 2nd Ed. T. L. Kirkpatrick and C. S. Rothrock, eds. American Phytopathological Society, St. Paul, MN.

Lawrence, G. W., McLean, K. S., Batson, W. E., Miller, D., and Borbon, J. C. 1990. Response of Rotylenchulus reniformis to nematicide applications on cotton. J. Nematol. 22:707-711.

Lawrence, K., Hagan, A., Olsen, M., Faske, T. R., Hutmacker, R., Mueller, J., Wright, D. L., Kemerait, R. C., Overstreet, C., Price, P., Lawrence, G. W., Allen, T. W., Atwell, S., Goldberg, N., Edmisten, K., Boman, R., Young, H., Woodward, J., and Mehl, H. 2017. Cotton Disease Loss Estimate Committee report, 2016. Pages 150-152 in: Proc. Beltwide Cotton Conf. Dallas, TX.

Lawrence, K., Hagan, A., Olsen, M., Faske, T. R., Hutmacker, R., Mueller, J., Wright, D. L., Kemerait, R. C., Overstreet, C., Price, P., Lawrence, G. W., Allen, T. W., Atwell, S., Goldberg, N., Edmisten, K., Boman, R., Young, H., Woodward, J., and Mehl, H. 2018. Cotton Disease Loss Estimate Committee report, 2017. Pages 161-163. Proc. Beltwide Cotton Conf. San Antonio, TX.

Lawrence, K., Huang, P., Lawrence, G., Faske, T., Overstreet, C., Wheeler, T., Young, H., Kemarait, R., and Mehl, H. 2015. Beltwide Nematode Research and Education Committee 2014 nematode research report cotton varietal and nematicide responses in nematode soils. Pages 739-742 in: Proc. Beltwide Cotton Conf. San Antonio, TX.

Lawrence, K., Lawrence, G., Faske, T., Overstreet, C., Wheeler, T., Young, H., Koenning, S., Mueller, J., Kemerait, R., and Mehl, H. 2014. Cotton variety and nematicide combinations for reniform and root-knot management across the cotton belt. Pages 295- 301 in: Proc. Beltwide Cotton Conf. New Orleans, LA.

Layton, B., and Reed, J. T. 2002. Biology and Control of Thrips on Seedling Cotton in Mississippi. Publication 2302. Mississippi State University Extension Service, Mississippi State, MS.

Lohmeyer, K. H., All, J. N., Roberts, P. M., and Bush, P. 2003. Precision application of aldicarb to enhance efficiency of thrips (Thysanoptera: Thripidae) management in cotton. J. Econ. Entomol. 96:748-754.

Monfort, W. S., Kirkpatrick, T. L., Long, D. L., and Rideout, S. 2006. Efficacy of a novel nematicidal seed treatment against Meloidogyne incognita on cotton. J. Nematol. 38:245-249.

Moore, S. R., Lawrence, K. S., Ortiz, B. V., Shaw, J. N., and Fulton, J. 2010. Evaluation of nematicides for the management of Rotylenchulus reniformis across management zones created using soil electrical conductivity. Phytopathology 100:S86.

National Cotton Council of America (NCC). 2007. The First 40 Days and Fruiting to Finish. NCC, Memphis, TN.

National Cotton Council of America (NCC). 2009. http://www.cotton.org/tech/ pest/nematode/distributions.cfm?state=07\&type $=$ Reniform .

Oostenbrink, M. 1960. Estimating nematode populations by some selected methods. Pages 85-201 in: Nematology: Fundamentals and Recent Advances with Emphasis on Plant Parasitic and Soil Forms. J. N. Sasser and W. R. Jenkins, eds. University of North Carolina Press, Chapel Hill, NC.

Overstreet, C., McGawley, E. C., Khalilian, A., Kirkpatrick, T. L., Monfort, W. S., Henderson, W., and Mueller, J. D. 2014. Site specific nematode management-Development and success in cotton production in the United States. J. Nematol. 46:309-320.

Patel, M. V. 1999. Cotton nematodes. Cooperative Extension Service, Field Crops M-132. Mississippi State University, Mississippi State, MS.

Penteado, M., Kirkpatrick, T. L., and Still, J. A. 2005. Effect of delayed infection by the root-knot nematode on damage to cotton. Page 147 in: Proc. Beltwide Cotton Conf. New Orleans, LA.

Robinson, A. F. 2007. Reniform in U.S. Cotton: When, where, why, and some remedies. Annu. Rev. Phytopathol. 45:263-288.

Robinson, A. F., Akridge, R., Bradford, J. M., Cook, C. G., Gazaway, W. S., Kirkpatrick, T. L., Lawrence, G. W., Lee, G., McGawley, E. C., Overstreet, C., Padgett, B., Rodriguez-Kabana, R., Westphal, A., and Young, L. D. 2005a. Vertical distribution of Rotylenchulus reniformis in cotton fields. J. Nematol. 37:265-271.

Robinson, A. F., Cook, C. G., Westphal, A., and Bradford, J. M. 2005b. Rotylenchulus reniformis below plow depth suppresses cotton yield and root growth. J. Nematol. 37:285-291.

Smith, A. L. 1940. Distribution and relation of meadow nematode, Pratylenchus pratensis, to Fusarium wilt of cotton in Georgia. Phytopathology 30:710.

Starr, J. L., Koenning, S. R., Kirkpatrick, T. L., Robinson, A. F., Roberts, P. A., and Nichols, R. L. 2007. The future of nematode management in cotton. J. Nematol. 39:283-294.

Stetina, S. R., Molin, W. T., and Pettigrew, W. T. 2010. Effects of varying planting dates and tillage systems on reniform nematode and browntop millet populations in cotton. Plant Health Prog. 11. doi: 10.1094/PHP-2010-1227-01-RS.

Stetina, S. R., Sciumbato, G. L., Young, L. D., and Blessitt, J. A. 2009. Cotton cultivars evaluated for tolerance to reniform nematode. Plant Health Prog. 10. doi: 10.1094/PHP-2009-0312-01-RS 
Stetina, S. R., Young, L. D., Pettigrew, W. T., and Bruns, H. A. 2007. Effect of corn-cotton rotations on reniform populations and crop yield. Nematropica 37:237-248.

Usery, S. R., Lawrence, K. S., Lawrence, G. W., and Burmester, C. H. 2005. Evaluation of cotton cultivars for resistance and tolerance to Rotylenchus reniformis. Nematropica 35:121-133.

Weaver, D. B. 2015. Cotton nematodes. Pages 547-570 in: Cotton. D. D. Fang and R. G. Percy, eds. American Society of Agronomy, Madison, WI.

Weaver, D. B., Lawrence, K. S., and Van Santen, E. 2007. Reniform nematode resistance in upland cotton germplasm. Crop Sci. 47:19-24.

Westphal, A., and Smart, J. R. 2003. Depth distribution of Rotylenchulus reniformis under different tillage and crop sequence systems. Phytopathology 93:1182-1189.
Wheeler, T. A., Lawrence, K. S., Porter, D. O., Keeling, W., and Mullinix, B. G., Jr. 2013. The relationship between environmental variables and response of cotton to nematicides. J. Nematol. 45:8-16.

Wheeler, T. A., Siders, K. T., Anderson, M. G., Russell, S. A., Woodward, J. E., and Mullinix, B. G., Jr. 2014. Management of Meloidogyne incognita with chemicals and cultivars in cotton in a semi-arid environment. J. Nematol. 46: 101-107.

Wrather, A., Stevens, G., Kellams, B., and Mauromoustakos, A. 2002. Sitespecific detection Meloidogyne incognita in cotton fields. Page 229 in: Proc. Beltwide Cotton Conf. Atlanta, GA.

Zimet, D. J., Smith, J. L., Rich, M. R., and Kinlock, R. A. 2002. Improving returns using nematicides in cotton fields infested with reniform nematodes in northwestern Florida. J. Cotton Sci. 6:34-39. 